\title{
Azalea Lace Bug, Stephanitis pyrioides (Scott) (Insecta: Hemiptera: Tingidae) ${ }^{1}$
}

Jamba Gyeltshen and Amanda Hodges ${ }^{2}$

\section{Introduction}

Azalea lace bug, Stephanitis pyrioides (Scott), belongs to a group of insects in the family Tingidae. The insects in this family generally live and feed on the underside of leaves. They have thin lacy outgrowths on their thorax, and have delicate lace-like forewings (Drake and Ruhoff 1965). At least 17 species of lace bugs cause damage to ornamental trees and shrubs in the United States (Buss et al. 2004).

Four species in the genus Stephanitis cause economic damage to plants in the heath family (Ericaceae) to which azaleas and rhododendrons belong (Mead 1967). Of the four, the most damaging species associated with landscape plants is the azalea lace bug, Stephanitis pyrioides (Cranshaw 2004).

Infested azaleas develop stippled, bleached, silvery or chlorotic symptoms similar to those caused by mites. Azalea lace bug is a pest of major concern in the nursery industry due to this aesthetic plant damage. Even in established landscape planting, azalea lace bugs can cause considerable damage to

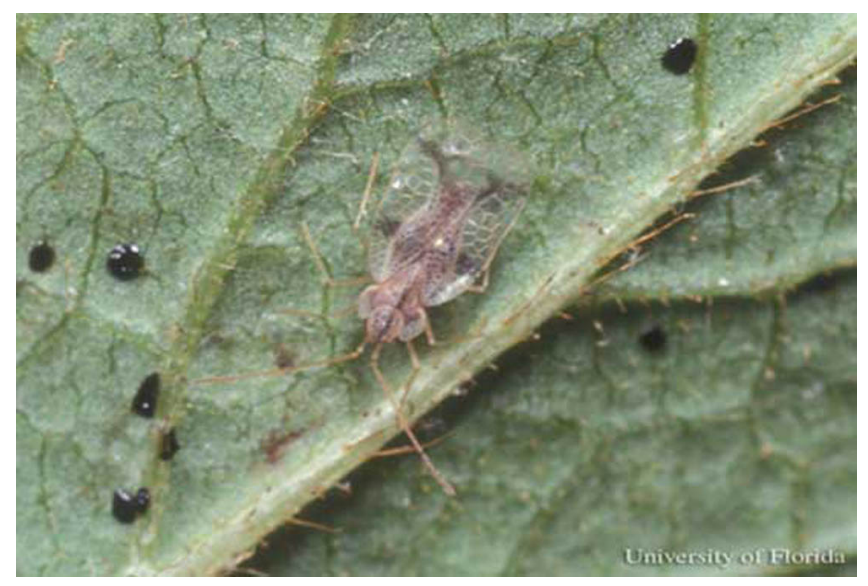

Figure 1. Adult azalea lace bug, Stephanitis pyrioides (Scott), and excrement. Credits: James. L. Castner, University of Florida

foliage if not controlled early in the season when populations are low.

\section{Distribution}

Native to Japan, the azalea lace bug spread around the world through the movement of its host species, azaleas (Mead 1967). It occurs in most of the eastern United States including Florida. Available records show that it occurs in the states of Maryland,

1. This document is EENY-373 (IN677), one of a series of Featured Creatures from the Entomology and Nematology Department, Florida Cooperative Extension Service, Institute of Food and Agricultural Sciences, University of Florida. Published: May 2006. This document is also available on Featured Creatures Website at http://creatures.ifas.ufl.edu. Please visit the EDIS Website at http://edis.ifas.ufl.edu.

2. Jamba Gyeltshen and Amanda Hodges, Department of Entomology and Nematology, University of Florida, Gainesville, FL 32611.

The Institute of Food and Agricultural Sciences (IFAS) is an Equal Opportunity Institution authorized to provide research, educational information and other services only to individuals and institutions that function with non-discrimination with respect to race, creed, color, religion, age, disability, sex, sexual orientation, marital status, national origin, political opinions or affiliations. U.S. Department of Agriculture, Cooperative Extension Service, University of Florida, IFAS, Florida A. \& M. University Cooperative Extension Program, and Boards of County Commissioners Cooperating. Larry Arrington, Dean 
New York, Massachusetts, Virginia, Georgia, Alabama, Texas and California (CABI 2005).

\section{Description}

Adult: The adult lace bug is $3 \times 1.5 \mathrm{~mm}(\sim 1 / 10$ inch) long and cream-colored. The netted lacy wings, marked with black or brown patches, are held flat over the body with outer margins extending beyond the body outline. Unless observed closely, the small size and transparent wings make it less apparent. When observed under a hand lens, a characteristic hood can be seen over the head.

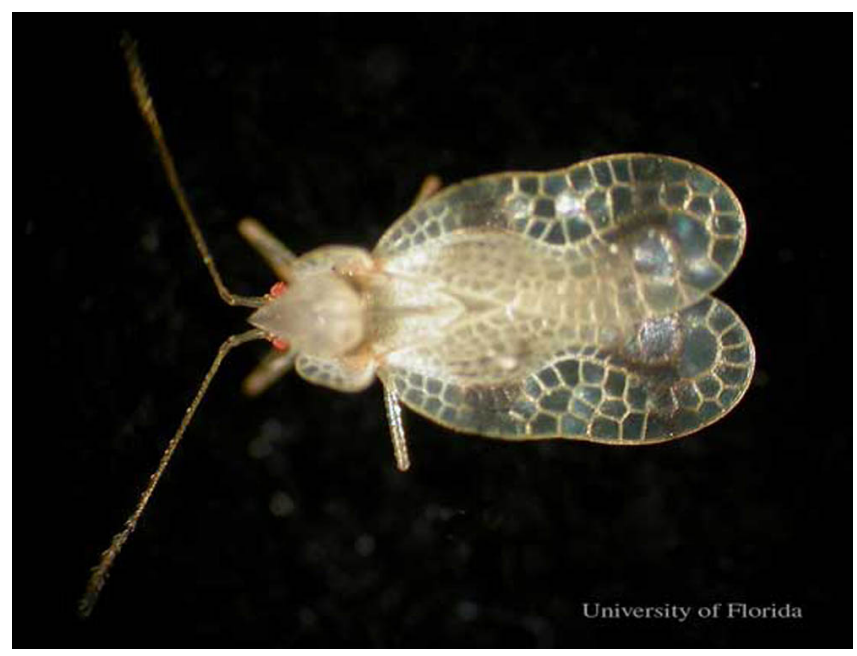

Figure 2. Adult azalea lace bug, Stephanitis pyrioides (Scott). Credits: Jamba Gyeltshen, University of Florida

Egg: The white oval or flask shaped egg is 0.36 to $0.43 \mathrm{~mm}$ ( 0.02 inch) long and 0.16 to $0.23 \mathrm{~mm}$ (0.02 inch) wide with a bent neck' to one side (Shen et al. 1985). Eggs are usually laid along the midrib or leaf margins of young leaves and covered with a dark brownish adhesive material that hardens to form a protective coating (Drake and Ruhoff 1965, Shen et al. 1985).

Nymph: The nymph is colorless upon hatching but soon turns black and spiny. It goes through five instars, ranging in size from $0.1 \mathrm{~mm}(0.004 \mathrm{inch})$ to $1.8 \mathrm{~mm}$ (0.07 inch). Wing pads can be seen after the fourth molt.

\section{Life History}

Females lay groups of partially embedded eggs on the underside of leaves, generally along the midrib but also on lateral veins and occasionally on the upper

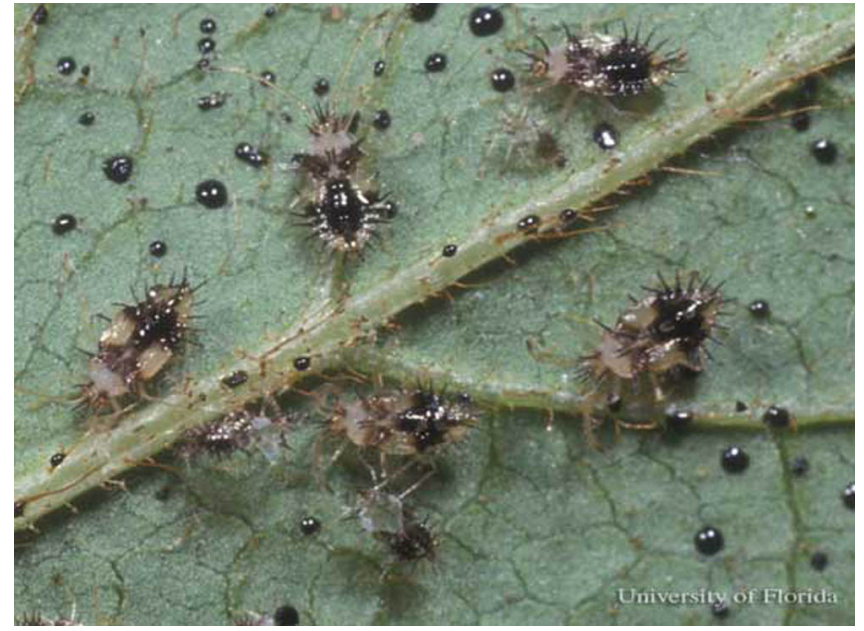

Figure 3. Nymphs of the azalea lace bug, Stephanitis pyrioides (Scott), with several cast skins and excrement. Credits: James. L. Castner, University of Florida

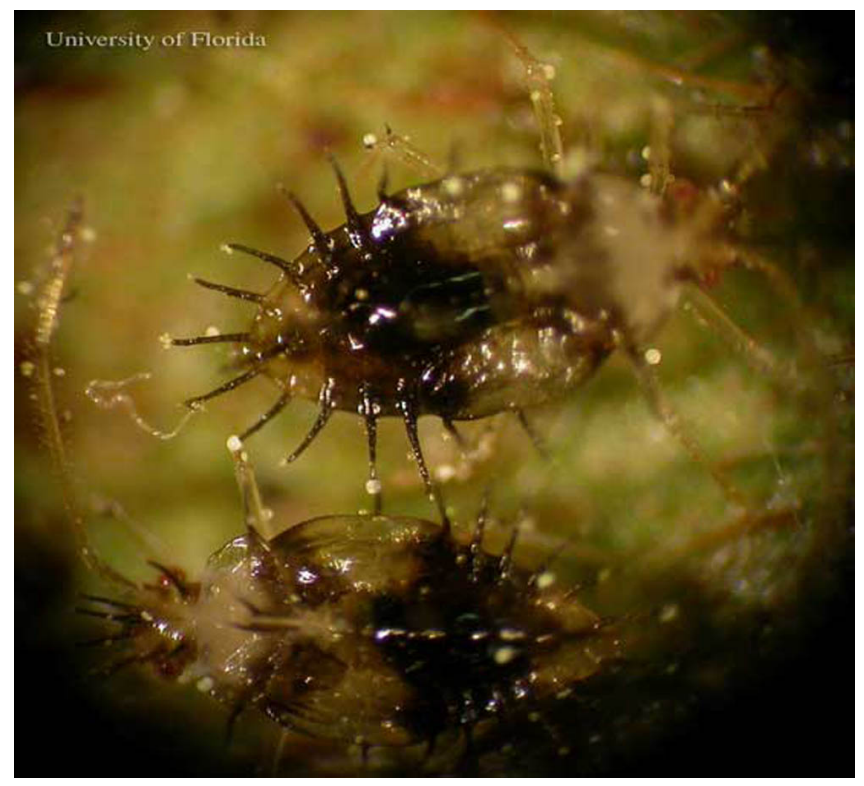

Figure 4. Nymphs of the azalea lace bug, Stephanitis pyrioides (Scott). Credits: Jamba Gyeltshen, University of Florida

leaf surface (Neal and Douglass 1988). Over 300 eggs, at the rate of five to seven eggs per day are laid during the adult stage. The development period of eggs vary from about 12 days at $31.7^{\circ} \mathrm{C}$ to 22 days at $20.6^{\circ} \mathrm{C}$ (Neal and Douglass 1988).

Nymphs emerge from the eggs and feed in small clusters, often near the empty eggshells. Their development through five instars also depends on temperature, taking 10.5 days at $31.7^{\circ} \mathrm{C}$ to about 23 days at $20.6^{\circ} \mathrm{C}$ (Neal and Douglass 1988). From egg to adult, it would take 22 to 45 days within a temperature range of 20.6 to $31.7^{\circ} \mathrm{C}$. The longevity 
of adult varies from one to four months under the same range of temperature (Neal and Douglass 1988). Between two to four generations are completed in a year. This species overwinters in the egg stage.

\section{Hosts Plant}

Recognition of the host plant is helpful in identifying lace bugs because they are generally fairly host-specific (Drake and Ruhoff 1965). The azalea lace bug is particularly injurious to evergreen azalea (Rhododendron spp.) varieties, although deciduous varieties may also be attacked.

\section{Damage}

Nymphs and adults cause damage by piercing and removing cell contents from leaf tissues. Adult females cause more feeding injury than adult males and nymphs (Buntin et al. 1996). Lace bugs insert their stylet through stomata on the lower leaf surface and feed almost entirely on upper palisade parenchyma (Ishihara and Kawai 1981, Buntin et al. 1996). Because of the removal of most of the chlorophyll containing tissues located near the upper epidermis, the leaf surface become stippled, bleached, silvery or chlorotic.

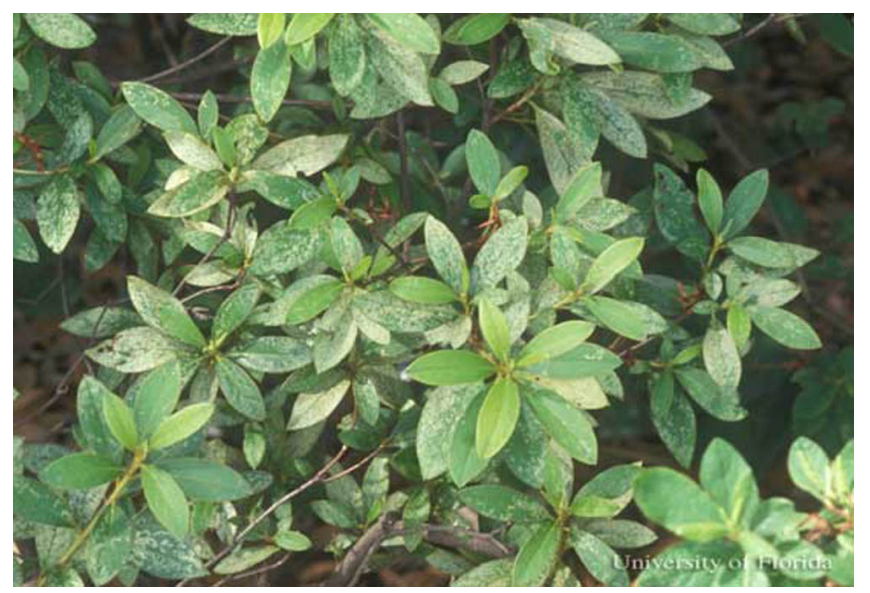

Figure 5. Damage caused by azalea lace bug, Stephanitis pyrioides (Scott), feeding. Credits: James. L. Castner, University of Florida

Severely damaged leaves become heavily discolored and eventually dry or fall off. Symptoms may sometimes be confused with mite injury, but the presence of brown varnish-like excrement, frequently

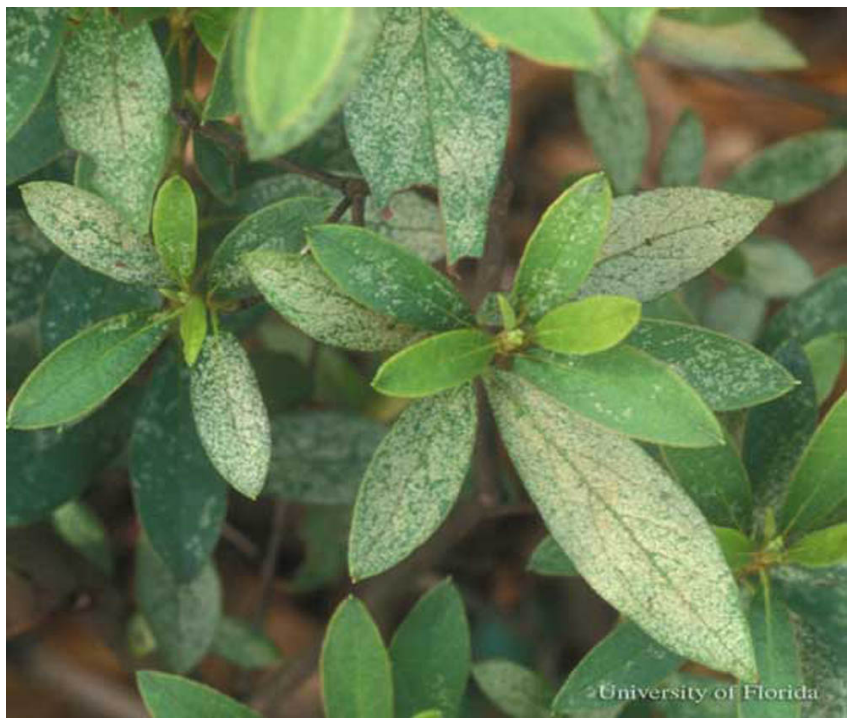

Figure 6. Damage caused by azalea lace bug, Stephanitis pyrioides (Scott), feeding. Credits: James. L. Castner, University of Florida

with cast skins attached, suggest lace bug damage (Johnson and Lyon 1991).

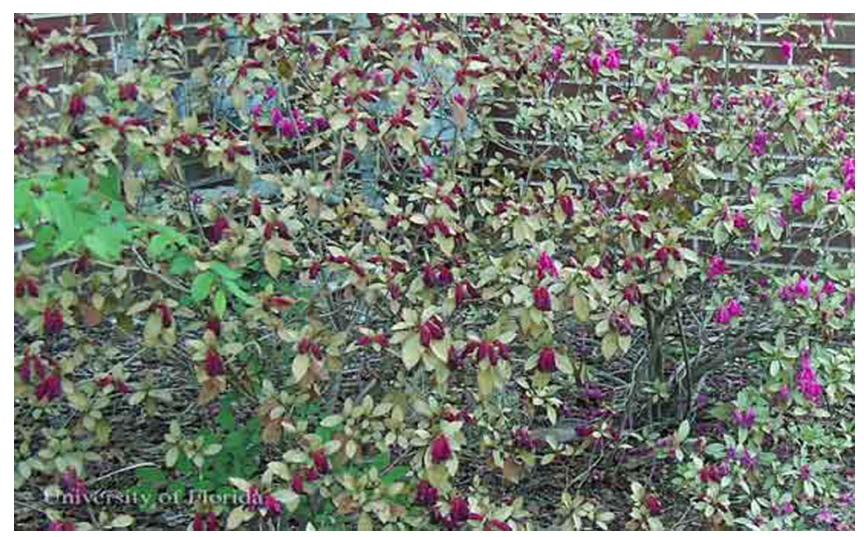

Figure 7. Severe damage caused by azalea lace bug, Stephanitis pyrioides (Scott), feeding. Credits: Jamba Gyeltshen, University of Florida

Generally, lace bug damage appears to be greater in sunny areas possibly because of a high rate of natural predation in the shade (Trumble and Denno 1995).

\section{Management}

Pest management decisions in ornamental plants are mainly influenced by aesthetic considerations as there will often be no acceptable level of apparent damage for sale of a nursery crop (Klingeman et al. 2001). Since early season damage on broadleaf evergreens may result in aesthetic injury for the 


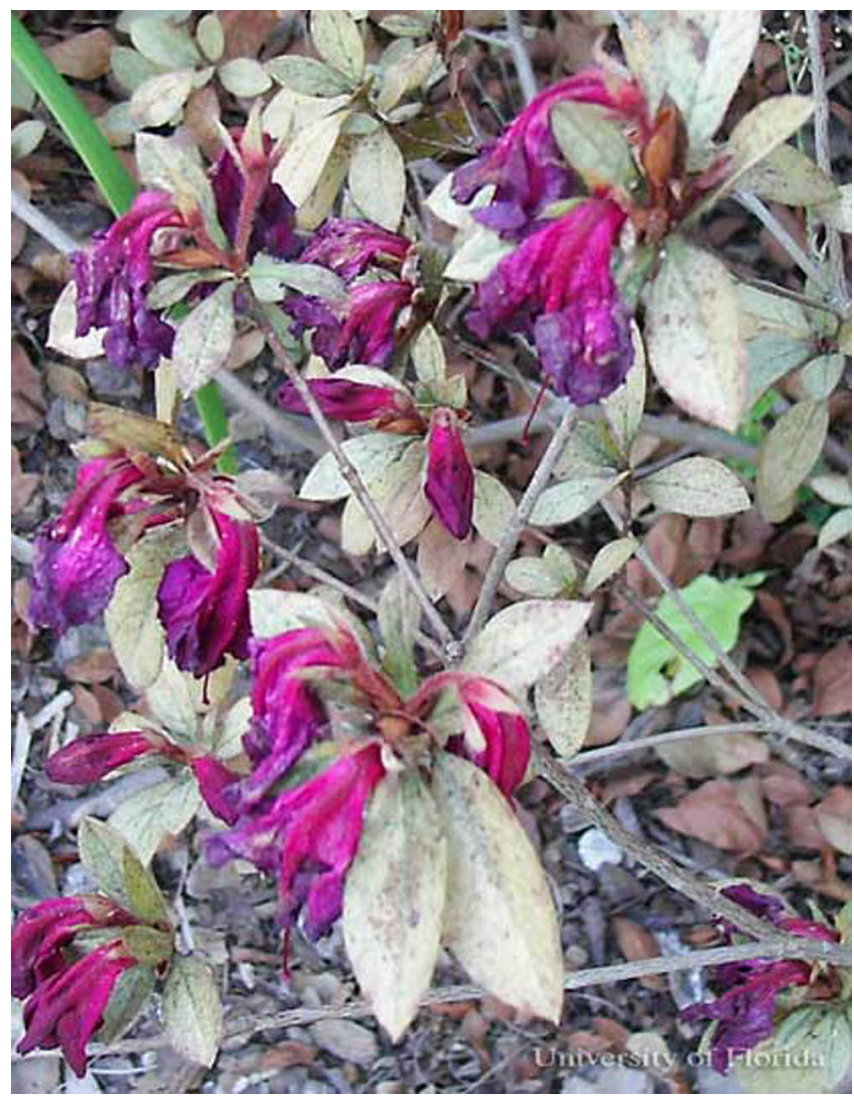

Figure 8. Severe damage caused by azalea lace bug, Stephanitis pyrioides (Scott), feeding. Credits: Jamba Gyeltshen, University of Florida

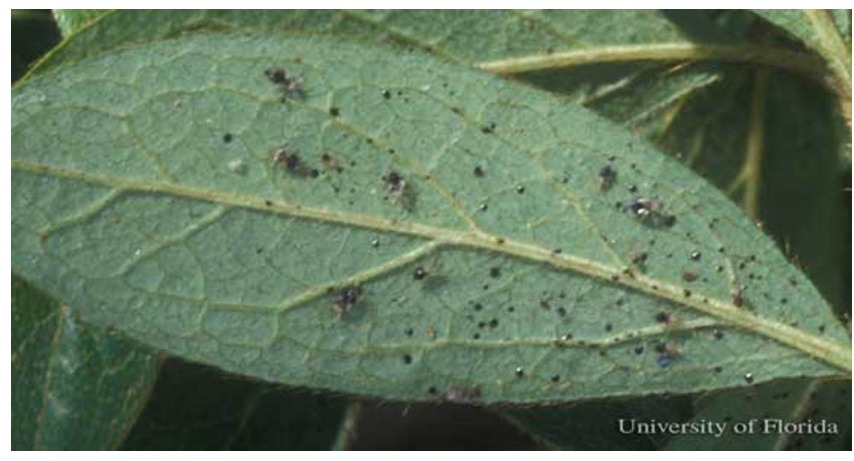

Figure 9. Azalea leaf with azalea lace bugs, Stephanitis pyrioides (Scott), and excrement spots. Credits: James. L. Castner, University of Florida

remainder of the growing season, it is important to control lace bugs early.

Monitoring. Plants should be monitored weekly in the spring, summer and fall for the presence of lace bugs (Buss et al. 2004). As initial damage symptoms may not be apparent, it is important to sample the leaves and observe the undersides with a powerful hand lens. Lace bugs can be also be detected by beating the shrub (to dislodge) and collecting them on a white sheet of paper.

Cultural control. Maintaining healthy plants with proper watering and fertilizer treatments reduces plant stress as well as damage potential. Growing azaleas in shadier areas also reduces damage.

Mechanical control. A hard jet of water from a garden hose could be directed on the undersides of the foliage to dislodge the bugs and possibly kill the nymphs, but any remaining live lace bugs may still damage the foliage.

Chemical control. Spring is the best time to control the first or second generation of lace bugs. Insecticidal soap, horticultural oil, neem oil and most synthetic insecticides provide good control (Reeves 2006). It is important to direct the spray to undersides of the leaves for optimal coverage. Some systemic insecticides could also provide season-long control if poured around the roots of azaleas in spring (Reeves 2006).

For chemical control under Florida conditions, see:

Insect Management Guide to Lace Bugs on Ornamental Plants (http://edis.ifas.ufl.edu/MG326)

Insect Management Guide for Landscape Plants (http://edis.ifas.ufl.edu/IG013).

\section{Selected References}

Buss EA, Turner JC, Short DE. (2004). Lace bugs of ornamental plants. EDIS. ENY-332. http://edis.ifas.edu/MG326 (12 March 2006).

Buntin GD, Braman SK, Gilbertz DA, Phillips DV. 1996. Chlorosis, photosynthesis, and transpiration of azalea leaves after azalea lace bug (Heteroptera: Tingidae) feeding injury. Journal of Economic Entomology 89:990-995.

CABI. (2005). Azalea lace bug, Stephanitis pyrioides (Hemiptera: Tingidae). Crop Protection Compendium. CAB International 2005.

Cranshaw W. 2004. The Ultimate Guide to Backyard Bugs: Garden Insects of North America. 
Princeton University Press, Princeton and Oxford. 384 pp.

Drake CJ, Ruhoff FA. 1965. Lace bugs of the World - A Catalog (Hemiptera: Tingidae). Smithsonian Institution, Washington D.C. United States National Museum Bulletin 213. 634 pp.

Ishihara R, Kawai S. 1981. Feeding habits of azalea lace bug, Stephanitis pyrioides $\mathrm{Scott}$ (Hemiptera: Tingidae). Japanese Journal of Applied Entomology and Zoology 25:200-202.

Johnson WT, Lyon HH. 1991. Insects that Feed on Trees and Shrubs. Comstock Publishing Associates, Cornell University Press, Ithaca and London.

Klingeman WE, Buntin GD, Braman SK. 2001. Using esthetic assessments of azalea lace bug (Heteroptera: Tingidae) feeding injury to provide thresholds for pest management decisions. Journal of Economic Entomology 94:1187-1192.

Mead FW. 1967. Stephanitis Lace Bugs of the United States (Hemiptera: Tingidae). Florida Department of Agriculture and Consumer Services, Division of PlantIndustry, Entomology Circular No. 62.

Mizell RF, Fasulo TR, Short DE. (2005). WoodyBug. UF/IFAS. http://woodypest.ifas.ufl.edu/ (15 May 2006).

Neal JW Jr., Douglass LW. 1988. Development, oviposition rate, longevity, and voltinism of Stephanitis pyrioides (Scott) (Heteroptera: Tingidae). Journal of Economic Entomology 93: 352-356.

Reeves W. (2006). Azalea lace bug - control. Gardening in Georgia. http://www.walterreeves.com/insects_animals/ article.phtml?cat=21\&id=521 (3 March 2006).

Shen HW, Wu WJ, Yang PS. 1985. The biology of the lacebug, Stephanitis pyrioides (Scott). Yen chiu pao kao (Memoirs of the College of Agriculture, National Taiwan University vol. 25, no 1, pp. 143-154).
Trumble RB, Denno RF. 1995. Light intensity, host-plant irrigation, and habitat-related mortality as determinants of the abundance of azalea lace bug (Heteroptera: Tingidae). Environmental Entomology 24: 898-908. 